\title{
The Environmental Law Enforcement In The Crime Of Forest Damage
}

\author{
Erlia Hendrasta*) and Achmad Sulchan**) \\ *) Kotabaru District Attorney E-mail: erronierlia84@gmail.com \\ **) Faculty of Law Universitas Islam Sultan Agung
}

\begin{abstract}
This study aims to determine and analyze environmental law enforcement in criminal acts of forest destruction during the Covid-19 pandemic. The approach method used is normative juridical research. The results of the study show that although the Covid-19 pandemic period is also very influential, the law enforcement process must still be carried out. One of the policies adopted by using teleconference technology. Not all trials are held virtually, the judge chooses and determines which cases can be carried out via video conference. For cases that are easy to prove, such as narcotics arresting hands, carrying sharp weapons and others. But for cases such as cases of fraud, murder and others held face to face. Virtual hearings are more suitable for reading indictments or charges. Meanwhile, the examination of witnesses is carried out face-to-face.
\end{abstract}

Keywords: Law Enforcement; Criminal Acts; Forest Destruction; Covid-19.

\section{Introduction}

One of Indonesia's natural resources that provide a lot of income for the state treasury is natural wealth in the form of forest products. The definition of forest according to Article 1 point 1 of Act No. 18 of 2013 concerning Prevention and Eradication of Forest Destruction: "Forest is an ecosystem unit in the form of a stretch of land containing biological natural resources which are dominated by trees in their natural environment community which cannot be separated between one and the other." Because forests are part of natural wealth and very valuable state assets for the prosperity and welfare of the Indonesian people, forests are also controlled by the state. This is in accordance with the provisions of Article 33 paragraph (3) of the 1945 Constitution of the Republic of Indonesia. This definition of controlled does not mean owned,

All forests within the territory of the Republic of Indonesia, including the natural resources contained therein, are controlled by the state for the greatest prosperity of the people. The state's control of forests is essentially aimed at achieving the maximum benefit of forests in a versatile and sustainable manner, either directly or indirectly, in the context of building a just and prosperous Indonesian society based on Pancasila.

Forests are not merely a collection of trees that are only exploited from wood products and other forest products, but a forest is a living community of biological nature or a complex plant community consisting of trees, shrubs, undergrowth, soil micro-organisms, animals and their natural environment. In addition to wood, there are also many mineral content found in the forests. Indonesia itself was awarded the abundant natural resources including minerals mining and Indonesia has a high 
dependence on the utilization of mining minerals such as capital construction. ${ }^{1}$ All of them have a relationship in a relationship of dependence on each other. So the forest is required to be able to maintain the balance of the ecological system of the environment, save all living things in it, store germplasm storage, maintain soil degradation and erosion, source industrial wood and local sawmills, source forest products for local residents as well as natural attractions, and especially for research. ${ }^{2}$

In the development of human life and civilization, forests are increasingly being used to meet the needs of life. Forest utilization is carried out in a very varied manner and intensity, ranging from uses that do not significantly affect the climax of the forest to actions that cause significant changes in forest composition. ${ }^{3}$

Forests are very beneficial for the greatest prosperity and welfare of the Indonesian people. The benefits can be divided into two types, namely direct and indirect benefits. The direct benefit of the forest is to produce wood that has high economic value and associated forest products, including rattan, latex, fruits, honey, and others. Meanwhile, there are eight indirect benefits of forests, including regulating water systems, preventing erosion, providing health benefits, providing a sense of beauty, providing benefits in the tourism sector, providing benefits in the field of defense and security, accommodating workers, and increase the country's foreign exchange.

Indonesia has a forest area of approximately 144 (one hundred and forty four) million hectares, only 118 (one hundred and eighteen) million hectares are still forest. The forest area is broken down into production forests covering an area of 49.3 (forty nine point three) million hectares, protected forests covering an area of 39.9 (thirty nine point nine) million hectares, and conservation forests and other forests covering an area of 29.0 (twenty) nine point zero) million hectares. ${ }^{4}$

Indonesia has a forest area with various types of plants. The forests are spread from the islands of Sumatra, Java, Bali, Nusa Tenggara, Kalimantan, Sulawesi, to Papua. Based on the 2015 Ministry of Environment and Forestry Statistics on the area of forest areas in Indonesia, the details are as follows: Conservation forest area: 27.4 million ha, Protected forest area: 29.7 million ha, Limited production forest area 26.8 million ha, Production forest area 29.3 million ha, convertible forest area 12.9 million ha, total forest area in Indonesia: 128 million ha. ${ }^{5}$

Based on data compiled from BPS on Indonesia's environmental statistics in 2011, Indonesia's forest area of 98.7 million hectares decreased in 2018 with only 93.5 million hectares remaining. This means that forests in Indonesia have decreased by 0.5 million to 1 million hectares every year. The decline was due to the

1 Kurniawan Daeli and Rakhmat Bowo Suharto. "Roles And Responsibilities Investigator In Investigation of Illegal Mining In Society Mining for Environmental Sustainability". Jurnal Daulat $\begin{array}{llllll}\text { Hukum } & \text { Volume } & 1 & \text { Issue } & 4 & \text { December }\end{array}$ http://jurnal.unissula.ac.id/index.php/RH/article/view/4144

${ }^{2}$ Arifin Arief. 2001. Hutan dan Kehutanan, Kanisius, Yogyakarta, p. 11 and 13.

${ }^{3}$ Sumardi and S.M.Widyastuti. 2004. Dasar-dasar Perlindungan Hutan, Gadjah Mada Universiry Press, Yogyakarta. p. 2.

${ }^{4}$ Salim H.S. 2004. Dasar-dasar Hukum Kehutanan, Sinar Grafika, Jakarta, p. 1.

5 Sebaran Luas Hutan Produksi di Indonesia dan Pemanfaatannya 2021, https://mutuinstitute.com/post/sebaran-luas-hutan-produksi-di-indonesia-dan-pemanfaatannya/ 
conversion of forest functions, illegal logging and mining without being followed by sustainable maintenance and conservation efforts. ${ }^{6}$

If such a large forest is managed and utilized as well as possible, it will have a positive impact in supporting the development of the nation and state. This means that the natural wealth that comes from the forest is truly priceless. ${ }^{7}$

However, the natural wealth that comes from the forest in the form of wood, and so on can also threaten the sustainability of the forest itself, for example illegal logging and illegal use of forest land by local communities. Protection and security are really needed so that forest sustainability can be maintained.

There are several losses suffered by the state because of this, namely the reduced state revenue from the forestry sector, the high cost of restoration that will be carried out by the state on damaged forest areas, and the low price of wood on the market, be it regional, national, or international markets because the stolen wood is of course sold at a very cheap price. ${ }^{8}$ Because of these losses, efforts to protect and safeguard the forest are needed.

Deforestation, especially in the form of illegal logging, mining without permits, and plantations without permits, has caused state losses, damaged sociocultural and environmental life, and increased global warming which has become a national, regional and international issue.

Forest destruction has become a crime that has extraordinary, organized and transnational impacts carried out with a sophisticated modus operandi, has threatened the survival of people's lives so that in the context of preventing and eradicating effective forest destruction and providing a deterrent effect, a strong and capable legal basis is needed ensure the effectiveness of law enforcement.

The term "forest damage" contained in the prevailing laws and regulations in the forestry sector is interpreted to mean that forest destruction contains a dualistic meaning, namely: first, forest damage that has a positive impact and obtains approval from the government cannot be categorized as an unlawful act. Second, damage that has a negative (harmful) impact is a real action against the law and against policy or without government approval in the form of a permit. ${ }^{9}$

Law enforcement in criminal acts of vandalism continues even during the Covid-19 pandemic. The Covid-19 pandemic has not dampened the enthusiasm of law enforcers in enforcing environmental laws, especially the issue of forest destruction.

Based on the description of the background of the problem above, this study aims to identify and analyze environmental law enforcement in criminal acts of breaking the law during the Covid-10 pandemic.

6 KLHK Diingatkan soal Penurunan Luas Lahan Hutan Indonesia, TribunNews, https://www.tribunnews.com/nasional/2021/02/05/klhk-diingatkan-soal-penurunan-luas-lahanhutan-indonesia

${ }^{7}$ Hasanu Simon. 2004. Membangun Kembali Hutan Indonesia, Pustaka Pelajar, Yogyakarta, p. 29.

${ }^{8}$ Salim HS, op.cit., p. 3.

${ }_{9}^{9}$ Bambang Tri Bawono and Anis Mashdurohatun. "Penegakan Hukum Pidana Di Bidang Illegal Logging Bagi Kelestarian Lingkungan Hidup Dan Upaya Penanggulangannya". Jurnal Hukum Vol XXVI, No. 2, August $2011 \quad$ p.593, http://jurnal.unissula.ac.id/index.php/jurnal Hukum/article/view/211/187 


\section{Research Method}

This research uses a normative juridical approach. The research specification used is analytical descriptive. The data used include secondary data, including primary legal materials, secondary and tertiary legal materials. Data collection methods used include the method of documentation or literature study. Methods of data analysis using qualitative analysis.

\section{Results and Discussion}

Development makes continuous use of natural resources to improve the welfare and quality of life of the people. Meanwhile, the availability of natural resources is limited and uneven, both in quantity and quality, while the demand for these natural resources is increasing as a result of increased development activities to meet the needs of an increasing and diverse population. On the other hand, the carrying capacity of the environment may be disturbed and the carrying capacity of the environment may decrease. Natural resources are divided into 2 (two), namely: 10

- Biological natural resources, such as plants and animals;

- Non-biological natural resources, such as water, soil, air, minerals, landscapes, and geological formations or manifestations of beautiful natural processes that are important to science.

In addition, natural resources can also be divided into: ${ }^{11}$

- Renewable natural resources, such as forests, fisheries, and others;

- Non-renewable natural resources, such as oil, coal, natural gas, and others.

Efforts to protect and secure forest functions are efforts to protect and limit forest damage and forest products caused by human and livestock actions, fires, natural forces, and disease, as well as to maintain and safeguard state rights to forests and forest products. ${ }^{12}$

There are two kinds of efforts to maintain, safeguard, and protect state rights to forests, namely forest protection efforts or called forest technical security efforts and forest security efforts or forest police security efforts. In other words, to anticipate forest destruction by Forest Concession Rights (HPH) permit holders, forest encroachers, and wood thieves, it is necessary to consistently enforce the law against the perpetrators regardless of ethnicity, religion, or social position, because everyone must be treated equally before the law. There are four factors that must be considered in consistently enforcing the law in the forestry sector, namely: ${ }^{13}$

- The existence of accommodative legal provisions, namely existing legal provisions must be able to solve problems that occur in the forestry sector. The existing legal provisions in the forestry sector are adequate because they regulate various matters, such as procedures for investigation, prosecution, and

\footnotetext{
10Koesnadi Hardjasoemantri. 1993. Hukum Tata Lingkungan, Gadjah Mada University Press, Yogyakarta, p. 25 and 26.

11 Salim HS, op.cit. p. 47

12Ibid., p. 99.

13 Ibid., p. 4.
} 
contain sanctions, namely administrative sanctions, civil sanctions, and criminal sanctions;

- The existence of strong, skilled, and moral law enforcers in the forestry sector, such as the forestry police, Polri, prosecutors, and judges;

- The existence of facilities that support the direction of law enforcement, such as typewriters, paper, and means of transportation;

- There is community participation in supporting law enforcement in the forestry sector, because without community participation, law enforcement is difficult to process.

If these four things are considered carefully and implemented as well as possible, it is hoped that forest damage in Indonesia can be prevented to a minimum in addition to efforts to protect and safeguard forests by law enforcement officials.

Efforts to enforce environmental law through criminal law are how the three main problems in criminal law are outlined in a law which more or less has a role to carry out social engineering, which includes the formulation of criminal acts (criminal act), criminal responsibility, and sanctions, both criminal and disciplinary. ${ }^{14}$

Forest damage caused by humans or natural forces can interfere with forest functions. Because of the importance of the existence of forests, it is necessary to make efforts for forestry development which is an effort to implement sustainable management of forest resources and use forests as much as possible for the prosperity of the people. For this reason, it is necessary to implement a forest management policy by: ${ }^{15}$

- Utilization of permanent forest areas;

- Improving the quality and productivity of state and community forest areas so that the income of the state and the people increases;

- Increasing efficiency and productivity of forest product management;

- Increasing community participation;

- Poverty alleviation of people living in and around the forest;

- Preservation of forests as protection of the environment and ecosystems;

- Increased supervision of forestry development;

- Forest management is a business which includes several aspects, such as planning, organization of implementation, implementation, monitoring, and evaluation of forests in which each function is interrelated and is a unity that influences each other.

Forest management is not just about strengthening the forest as a protection for soil, climate, water sources, and fulfilling the need for wood and other products. But forest management must be aimed at utilizing all land for the benefit of the state, even other countries as well. Thus, partially understood about the hydrological function, biological support, soil fertility, economy, social, culture, recreation, and aesthetics of the forest as a whole. Meanwhile, as a whole or comprehensively, it is

\footnotetext{
${ }^{14}$ Wahyu Lukito, "Implementasi Pelestarian Lingkungan Hidup Dalam Bidang Penegakan Hukum Pidana Terhadap Kasus Illegal Logging (Studi Kasus Polres Rembang)". Jurnal Hukum Khaira Ummah $\begin{array}{llllll}\text { Vol. } & 13 . & \text { No. } & 1, & \text { March, } & 2018 .\end{array}$ 159.http://jurnal.unissula.ac.id/index.php/ihku/article/view/2593/1949

${ }^{15}$ Arifin Arief, op.cit., p. 93.
} 
necessary to pay attention to the relation of one function and problem to another function and problem.

In the development of human life and civilization, forests are increasingly being used to meet the needs of life. However, the natural wealth that comes from the forest in the form of wood, and so on can also threaten the sustainability of the forest itself, for example illegal logging and illegal use of forest land by local communities.

Deforestation, especially in the form of illegal logging, mining without permits, and plantations without permits, has caused state losses, damaged sociocultural and environmental life, and increased global warming which has become a national, regional and international issue.

Forest destruction has become a crime that has extraordinary, organized and transnational impacts carried out with a sophisticated modus operandi, has threatened the survival of people's lives so that in the context of preventing and eradicating effective forest destruction and providing a deterrent effect, a strong and capable legal basis is needed.

Forests that have a high enough economic value, so that exploitation of the forest continues from time to time. Humans are the suspects of deforestation, forest exploitation and environmental chaos that occurs. The government and law enforcement must give the strongest punishment to the perpetrators of forest destruction indiscriminately. A firm attitude by the government and law enforcers to environmental destroyers will be the main gate in the environmental conservation program.

Prohibited actions which are categorized as acts of forest destruction are contained in the formulation of Article 12, Article 14, Article 15, Article 17, Article 19 - Article 28 of Act No. 18 of 2013 concerning Prevention and Eradication of Forest Destruction, while the criminal provisions for The crime of forest destruction is regulated in Chapter X Article 82 - Article 109 of Act No. 18 of 2013 concerning Prevention and Eradication of Forest Destruction.

The sanctions that will be imposed on acts of forest destruction vary, depending on the type of act. The imposition of sanctions on people who destroy forests is carried out through a law enforcement process. The process of law enforcement against acts of forest destruction includes investigations by the Police and Civil Servant Investigators (PPNS) who are appointed from employees within the Ministry of Forestry who are given special authority to conduct investigations, prosecution by Public Prosecutors, and trial examinations by judges. ${ }^{16}$

The crime of forest destruction is snared with severe penalties, considering the enormous impact of forest destruction on human survival and the environment.

The current formulation of the illegal logging crime still categorizes an act of forest destruction on the basis of the presence or absence of a permit, legal or illegal action of a person or legal entity. The law seems to construct the issue of illegal logging as a legal or illegal issue, not on the impact that the forest has actually been damaged, so that the benchmark in its application is whether a business or activity carried out by a person has a permit or not. . This can be interpreted, that if a person

${ }^{16}$ Indra Ch. R. Tihirang, Penegakan Hukum Terhadap Kejahatan Di Bidang Ke-hutanan, Jurnal Lex Crimen, Vol. 3 No. 6, 2013, Faculty of Law, Universitas Sam Ratulangi, Manado,, p. 132-134. 
has a permit then he does not commit a crime of illegal logging, on the contrary if he does not have a permit then he has committed a criminal act of illegal logging. ${ }^{17}$

In another study it was concluded that the judge's obstacle in deciding cases of illegal logging was in the form of difficulty in distinguishing between illegal logging carried out by individuals and corporations, there was no special education for judges to handle cases of illegal logging still unable to dismantle the network of corporations that carry out illegal logging that orders individuals to carry out illegal logging. 18

Healthy forests can play an important role in building a resilient economy and society in the face of a pandemic, climate change, and other global challenges, so that environmental law enforcement during the Covid-19 pandemic will continue to be carried out and intensify criminal sanctions for perpetrators of environmental destruction as the case above.

Law enforcers, while still paying attention to government policies regarding the handling of the Covid-19 pandemic, also continue to process the law for perpetrators of environmental destruction. The innovation was carried out to conduct trials, namely online hearings to see the condition of detainees in detention centers and prisons during the emergency period of the Corona virus disease outbreak in Indonesia. Detainees who take part in the trial process via video conference are detainees whose detention extensions are no longer possible.

During the trial process, detainees will remain in the prison/remand center, the Prosecutor in the Prosecutor's Office and the Judge in court or adjust to the conditions of each region. The public can also participate in the trial as long as the trial is declared open to the public.

Not all trials are held virtually, the judge chooses and determines which cases can be carried out via video conference. For cases that are easy to prove, such as narcotics arresting hands, carrying sharp weapons and others. But for cases such as cases of fraud, murder and others held face to face.

Virtual hearings are more suitable for reading indictments or charges. Meanwhile, the examination of witnesses was conducted face-to-face. This instruction is carried out as a step to prevent the spread of the Covid-19 virus in the judiciary by implementing social or physical (social distancing measure or physical distancing).

In the midst of the current Covid-19 outbreak, law enforcers still have to complete the legal process for various criminal cases. With improvised equipment, law enforcers remain enthusiastic about coordinating with other law enforcement officers to hold hearings via teleconference. The trial by teleconference is an achievement of Indonesian law enforcement in the midst of the Covid-19 virus outbreak. While in other parts of the world many courts are closed, in Indonesia they

\footnotetext{
${ }^{17}$ Dwi Agus Istiyono. "Illegal Logging Criminal Investigation Process". Law Development Volume 2 Issue 3 , September 2020, p. 430.http://jurnal.unissula.ac.id/index.php/ldj/article/view/11992/4966

${ }^{18}$ Muslich Ashari1, Amin Purnawan, and Achmad Sulchan. "Criminal Sanctions On Illegal Logging Crime In State Court Of Semarang". Jurnal Daulat Hukum Volume 2 Issue 4, December 2019. p. 467http://jurnal.unissula.ac.id/index.php/RH/article/view/8346/3866
} 
can still be implemented. The trial in the court must not stop even in the current state of the Covid-19 pandemic.

As it is known that in response to the COVID-19 Pandemic situation that broke out in early 2020, the Supreme Court issued SEMA No. 1 of 2020 concerning Guidelines for the Implementation of Duties During the Prevention of the Spread of Corona Virus Disease 2019 (COVID-19) within the Supreme Court of the Republic of Indonesia and the Judicial Bodies Under it, as last modified by SEMA No. 6 of 2020. Through this SEMA, the Supreme Court instructs civil, religious and state administrative cases to be tried through E-Litigation or an electronic trial. Regarding criminal cases, jinayat, and military crimes, the Supreme Court has instructed trials during the COVID-19 pandemic to continue as usual in court. specifically for cases where the defendant is being detained and the detention period cannot be extended any longer during the period of preventing the spread of COVID-19. For cases with defendants whose detention period can still be extended, the trial is postponed until the end of the COVID-19 prevention period.

From the legal aspect, the teleconference trial is still valid because the trial continues even though those involved in a trial are not in the same room. Online trial in court is also part of public service, especially for justice seekers.

Law enforcement in criminal acts of vandalism continues even during the Covid-19 pandemic. The Covid-19 pandemic has not dampened the enthusiasm of law enforcers in enforcing environmental laws, especially the issue of forest destruction. However, even in the conditions of the Covid-19 pandemic, law enforcement must not stop. It is inconceivable that if the law cannot be enforced in a day or even an hour, chaos or turmoil can occur everywhere. ${ }^{19}$

Prohibited actions which are categorized as acts of forest destruction are contained in the formulation of Article 12, Article 14, Article 15, Article 17, Article 19 - Article 28 of Act No. 18 of 2013, while the criminal provisions for criminal acts of forest destruction are regulated in Chapter X Article 82 - Article 109 of Act No. 18 of 2013. The sanctions that will be imposed on acts of forest destruction are different, depending on the type of act. The imposition of sanctions on people who destroy forests is carried out through a law enforcement process. The process of law enforcement against acts of forest destruction includes, investigations by the Police and Civil Servant Investigators (PPNS) who are appointed from employees within the Ministry of Forestry who are given special authority to conduct investigations, prosecution by the Public Prosecutor, and examination of the trial by the judge. In the midst of the current Covid-19 outbreak, law enforcers still have to complete the legal process for various criminal cases. The innovation was carried out to conduct trials, namely online hearings to see the condition of detainees in detention centers and prisons during the emergency period of the Corona virus disease outbreak in Indonesia.

\section{Closing}

${ }^{19}$ Nano Tresna Arfana. "Ketua MK: Penegakan Hukum Tidak Boleh Berhenti di Masa Pandemi". https://www.mkri.id/index.php?page=web.Berita\&id=17156\&menu=2 
Although the Covid-19 pandemic period is also very influential, the law enforcement process must still be carried out. One of the policies adopted by using teleconference technology. Not all trials are held virtually, the judge chooses and determines which cases can be carried out via video conference. For cases that are easy to prove, such as narcotics arresting hands, carrying sharp weapons and others. But for cases such as cases of fraud, murder and others held face to face. Virtual hearings are more suitable for reading indictments or charges. Meanwhile, the examination of witnesses is carried out face-to-face.

\section{References}

\section{Journal}

[1] Arifin Arief. 2001. Hutan dan Kehutanan, Kanisius, Yogyakarta, p. 11 and 13.

[2] Bambang Tri Bawono and Anis Mashdurohatun. "Penegakan Hukum Pidana Di Bidang Illegal Logging Bagi Kelestarian Lingkungan Hidup Dan Upaya Penanggulangannya". Jurnal Hukum Vol XXVI, No. 2, August 2011 p.593,http://jurnal.unissula.ac.id/index.php/jurnal Hukum/article/view/211/187

[3] Dwi Agus Istiyono. "Illegal Logging Criminal Investigation Process". Law Development Volume 2 Issue 3, September 2020, p. 430.http://jurnal.unissula.ac.id/index.php/ldj/article/view/11992/4966

[4] Indra Ch. R. Tihirang, Penegakan Hukum Terhadap Kejahatan Di Bidang Kehutanan, Jurnal Lex Crimen, Vol. 3 No. 6, 2013, Faculty of Law, Universitas Sam Ratulangi, Manado,, p. 132-134.

[5] Kurniawan Daeli and Rakhmat Bowo Suharto. "Roles And Responsibilities Investigator In Investigation of Illegal Mining In Society Mining for Environmental Sustainability". Jurnal Daulat Hukum Volume 1 Issue 4 December http://jurnal.unissula.ac.id/index.php/RH/article/view/4144

2018,

[6] Muslich Ashari1, Amin Purnawan, and Achmad Sulchan. "Criminal Sanctions On Illegal Logging Crime In State Court Of Semarang". Jurnal Daulat Hukum

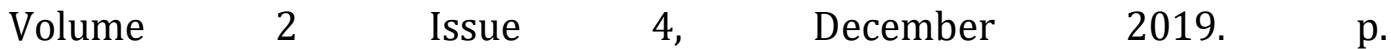
467http://jurnal.unissula.ac.id/index.php/RH/article/view/8346/3866

[7] Wahyu Lukito, "Implementasi Pelestarian Lingkungan Hidup Dalam Bidang Penegakan Hukum Pidana Terhadap Kasus Illegal Logging (Studi Kasus Polres Rembang)". Jurnal Hukum Khaira Ummah Vol. 13. No. 1, March, 2018. Pg. 159.http://jurnal.unissula.ac.id/index.php/ihku/article/view/2593/1949

\section{Book}

[1] Hasanu Simon. 2004. Membangun Kembali Hutan Indonesia, Pustaka Pelajar, Yogyakarta

[2] Koesnadi Hardjasoemantri. 1993. Hukum Tata Lingkungan, Gadjah Mada University Press, Yogyakarta

[3] Salim H.S. 2004. Dasar-dasar Hukum Kehutanan, Sinar Grafika, Jakarta

[4] Sumardi and S.M.Widyastuti. 2004. Dasar-dasar Perlindungan Hutan, Gadjah Mada Universiry Press, Yogyakarta 


\section{Internet}

[1] KLHK Diingatkan soal Penurunan Luas Lahan Hutan Indonesia, TribunNews, https://www.tribunnews.com/nasional/2021/02/05/klhk-diingatkan-soalpenurunan-luas-lahan-hutan-indonesia

[2] Nano Tresna Arfana. "Ketua MK: Penegakan Hukum Tidak Boleh Berhenti di Masa Pandemi". https://www.mkri.id/index.php?page=web.Berita\&id=17156\&menu=2

[3] Sebaran Luas Hutan Produksi di Indonesia dan Pemanfaatannya 2021, https://mutuinstitute.com/post/sebaran-luas-hutan-produksi-di-indonesiadan-pemanfaatannya/ 